Bull. Fac .Agric., Cairo Univ. 64:30-36 (2013)

\title{
EFFECT OF PARTICLES SIZE OF SOME CEREAL BRANS ON THE QUALITY OF HIGH FIBER BALADY BREAD
}

\author{
(Received: 16.1.2013) \\ By \\ M. M.Iraqui, N. A. Ali and A. S. Barakat \\ Food Technology Research Institute,Agriculture Research Center, Giza
}

\begin{abstract}
This research aims to study effect of the bran particle size of wheat, barley, oats, sorghum and maize as dietary fiber sources with positive health effects on the quality of the high-fiber bread. Grains were milled to produce the bran. Then, the bran were re-milled and sieved on $500 \mu \mathrm{m}$ sieve to separate coarse bran (greater than $500 \mu \mathrm{m}$ ) and fine bran (less than $500 \mu \mathrm{m}$ ). The results showed high levels of these cereal brans of insoluble and soluble dietary fibers, proteins (except maize bran), minerals and water holding capacity and low content of carbohydrates. Coarse bran had high content in total dietary fiber and low content in carbohydrates compared with fine bran which had high water holding capacity. All kinds of brans were replaced with $10 \%$ of the wheat flour $82 \%$ extraction rate to produce high-fiber bread. Dietary fiber, moisture and water holding capacity leveld were increased in the produced high fiber bread compared with the control Balady bread. Also, moisture content and water holding capacity of the bread containing fine fiber were higher than the bread containing the coarse bran due to the increasing surface area of the fine bran. Bran of wheat, barley and sourghum recorded sensory properties better than bran of oat and maize. Also, effect of fine bran on sensory properties and freshness of the produced high fiber bread were better than coarse bran. The results recommended the possibility of producing healthy high-fiber bread using cereal brans with $10 \%$ of wheat flour without significant deteriorations in the sensory properties of bread.
\end{abstract}

Key words: Balady bread, high fiber, physical properties.

\section{INTRODUCTION}

Epidemiological and clinical studies demonstrate that consumption of dietary fiber and whole grain intake is inversely related to obesity (Tucker and Thomas, 2009), type two diabetes (Meyer, et al., 2000), cancer (Park et al., 2009) and cardiovascular disease (CVD) (Streppel, et al., 2008). Cereal brans are a major category of dietary fiber and one that is particularly beneficial in promoting gut health and avoiding a range of diseases (Cho et al., 2004). Also, cereal brans are known to have substantial concentrations of important nutrients such as soluble and insoluble fibers (Chronakis, et al., 2004), minerals, vitamins, proteins and lipids (Murtaugh et al., 2003). A major field of research is therefore centered on the incorporation of cereal brans into cereal-based and other food products, in forms that are attractive to consumers, as the basis for couraging healthy diets. Cereal- based foods frequently derive their appeal from an aerated structure and bran is generally detrimental to the creation of aerated structures in these products (Campbell, 2003). Several workers have therefore studied the incorporation of bran into less aerated products including cakes, biscuits, muffins, breakfast cereals, snack foods, flat breads and pizza (De Delahaye et al., 2005). Dietary fiber and whole grains contain a unique blend of bioactive components including resistant starches, vitamins, minerals, phytochemicals and antioxidants. As a result, research regarding their potential health benefits has received considerable attention in the last several decades. Brans increased the fecal concentration of sugars, bacterial mass, nitrogen, ash, fat and mass of plant material. Wheat bran contains $90 \%$ fiber and only $50-60 \%$ of oat bran fiber is insoluble (Chen, et al., 1998). Cereal fibers can be used in the food industry as functional ingredients with excellent results (Viuda-Martos et al., 2010). Corn bran is 
produced in yields of about $6 \%-7 \%$ of total corn kernel. Corn bran contains potentially useful components that may be harvested through physical, chemical or enzymatic means for the production of food ingredients or additives, including corn fiber oil, corn fiber gum, cellulosic fiber gels, xylo-oligosaccharides and ferulic acid (Watson,2003).De Kock et al.,(1999) demonstrated that bran particle size affects quality when added to bread and found that smaller particle sizes decreased loaf volume more than larger particle sizes. In cookies, Ozturk et al., (2002) reported that medium $(212-425 \mu \mathrm{m})$ and coarse $(425-850 \mu \mathrm{m})$ particle sizes gave better spread ratios, color and overall sensory scores compared with cookies made with finer particle sizes $(<212 \mu \mathrm{m})$. Kumar et al., (2011) reported that Wheat is an excellent source of iron and phosphorus. The objective of this research was to evaluate the effect of particle size of some cereal brans on sensory characteristics and staling of the high-fiber balady bread.

\section{MATERIALS AND METHODS}

Wheat, barley, oat, sorghum and maize were obtained from Field Crops Research Institute, Giza, Egypt. Wheat flour (82\% extraction) was obtained from South Cairo Mills Co. Yeast and salt were purchased from the local market.

2.1. Preparation of Grains bran: Grains were milled to produce the bran. Then, the resulted brans were re-milled and sieved on 500 micron sieve to separate coarse bran (greater than 500 microns) and fine bran (less than 500 microns).

2.2. Preparation of Balady bread: Coarse and fine brans of wheat, barley, oat, sorghum and corn were replaced with $10 \%$ of wheat flour $(82 \%$ extraction) to prepare wheat flour blends. Yeast, salt and water were added to the previous blends with $3 \mathrm{~g}, 2 \mathrm{~g}$ and $100 \mathrm{ml}$, respectively. High fiber balady bread was prepared according to (Sallam $e t$ al., 1995) in the experimental bakery of Food Technology Research Institute.

2.3. Sensory evaluation of bread: Bread quality attributes were evaluated after cooling during 30 min for crust and crumb attribute determinations. Appearance (15), layers separation (15), crumb texture (15), crust color (15), taste (20), odor (20) and overall acceptability (100) were determined according to (Faridi and Rubenthaler, 1984) with some modifications. Sensory characteristics were determined by ten panelists from the staff members of the Food Technology Research Institute, Agricultural Research Center, Giza, Egypt.

2.4. Determination of staling rate: The staling rate of bread was measured by determination of alkaline water retention capacity (A.W.R.C) using the method of (Kitterman and Rubenthaler, 1971).

2.5. Gross chemical composition: Moisture, crude proteins, lipids, total dietary fibers (TDF), soluble (SDF) and insoluble dietary fibers (IDF) and ash contents of wheat flour (82\% extraction), cereal brans and produced bread were determined by the standard procedures described in the A.O.A.C. (2005). Total carbohydrates were calculated by difference according to the following equation: Total carbohydrates $=100-$ ( $\%$ crude proteins $+\%$ crude fats $+\%$ ash). Total calories were calculated using the equation mentioned by FAO/ WHO (1974). Where, energy $($ calories $)=4$ (carbohydrate + protein $)+9$ (fat) .

2.6.Determination of minerals: Calcium was determined by EDTA titration according to the method recommended by the A. O. A. C. (2005). Iron, zinc, potassium and manganese were determined using atomic absorption spectrophotometer (Perkin Elmer Instrument Model 2380) according to the methods recommended by the A. O. A. C. (2005).

2.7. Statistical Analysis: Data were statistically analyzed by the variance and least significant difference (L.S.D) at 0.05 level according to the method described by McClave, and Benson (1991).

\section{RESULTS AND DISCUSSION \\ 3.1. Chemical composition of wheat flour and cereal brans: \\ Chemical composition of wheat flour and} cereal brans is shown in Table (1). Data demonstrated that total dietary fibers (TDF), proteins, fats, carbohydrates, and ash content in coarse bran were similar to that in the fine with some minor differences. Data showed also that TDF content of corn, barley and wheat was high in comparison with sorghum and oat. Also, sorghum and oat bran had high carbohydrate content. Also barley, wheat and oat brans had high ash content. In contrast, corn bran had the lowest content of proteins, carbohydrates and ash.

3.2. Dietary fiber components and water retention capacity of wheat flour and cereal brans: 
Table (1): Chemical composition of wheat flour and cereal brans:

\begin{tabular}{|l|c|c|c|c|c|}
\hline Raw materials & $\begin{array}{c}\text { Carb } \\
\text { ohydr } \\
\text { ates } \\
(\%)\end{array}$ & $\begin{array}{c}\text { TDF } \\
(\%)\end{array}$ & $\begin{array}{c}\text { Prote } \\
\text { ins } \\
(\%)\end{array}$ & $\begin{array}{c}\text { Fats } \\
(\%)\end{array}$ & $\begin{array}{c}\text { Ash } \\
(\%)\end{array}$ \\
\hline $\begin{array}{l}\text { Wheat flour } \\
(82 \%)\end{array}$ & 78.9 & 5.1 & 13.5 & 1.7 & 0.8 \\
\hline $\begin{array}{l}\text { Coarse wheat } \\
\text { bran }\end{array}$ & 31.8 & 45.1 & 15.1 & 3.7 & 4.3 \\
\hline Fine wheat bran & 34.8 & 43.5 & 15.3 & 3.3 & 3.1 \\
\hline $\begin{array}{l}\text { Coarse barley } \\
\text { bran }\end{array}$ & 26.6 & 47.5 & 18.8 & 2.3 & 4.8 \\
\hline $\begin{array}{l}\text { Fine barley } \\
\text { bran }\end{array}$ & 29.7 & 44.8 & 19.2 & 1.3 & 5.0 \\
\hline Coarse oat bran & 39.6 & 34.9 & 16.0 & 5.5 & 4.0 \\
\hline Fine oat bran & 42.5 & 30.3 & 16.7 & 5.7 & 4.8 \\
\hline $\begin{array}{l}\text { Coarse sorghum } \\
\text { bran }\end{array}$ & 50.4 & 35.5 & 13.3 & 0.1 & 0.7 \\
\hline $\begin{array}{l}\text { Fine sorghum } \\
\text { bran }\end{array}$ & 52.4 & 33.4 & 13.0 & 0.2 & 1.0 \\
\hline $\begin{array}{l}\text { Coarse corn } \\
\text { bran }\end{array}$ & 14.6 & 77.5 & 5.3 & 2.0 & 0.6 \\
\hline Fine corn bran & 10.5 & 80.0 & 7.0 & 1.8 & 0.7 \\
\hline
\end{tabular}

${ }^{\mathrm{a}}$ indicates total dietary fibers

Table (2): Dietary fiber component and water retention capacity of wheat flour and cereal brans:

\begin{tabular}{|l|c|c|c|c|}
\hline \multicolumn{1}{|c|}{ Raw materials } & $\begin{array}{c}\text { TD } \\
\mathbf{F}^{\mathbf{a}} \\
(\boldsymbol{\%})\end{array}$ & $\begin{array}{c}\text { IDF } \\
\mathbf{b} \\
(\boldsymbol{\%})\end{array}$ & $\begin{array}{c}\text { SD } \\
\mathbf{F}^{\mathbf{c}} \\
(\boldsymbol{\%})\end{array}$ & $\begin{array}{c}\text { AWR } \\
\mathbf{C}^{\mathbf{d}} \\
(\boldsymbol{\%})\end{array}$ \\
\hline Wheat flour $(\mathbf{8 2 \% )}$ & 4.1 & 1.3 & 2.8 & - \\
\hline Coarse wheat bran & 45.1 & 41.8 & 3.3 & 253.0 \\
\hline Fine wheat bran & 43.5 & 38.9 & 4.6 & 277.5 \\
\hline Coarse barley bran & 47.5 & 34.2 & 13.3 & 280.2 \\
\hline Fine barley bran & 44.8 & 30.3 & 14.5 & 290.4 \\
\hline Coarse oat bran & 30.3 & 21.0 & 9.3 & 265.4 \\
\hline Fine oat bran & 34.9 & 23.5 & 11.4 & 280.5 \\
\hline Coarse sorghum bran & 35.5 & 30.4 & 5.1 & 165.9 \\
\hline Fine sorghum bran & 33.4 & 26.2 & 7.2 & 230.5 \\
\hline Coarse corn bran & 77.5 & 76.0 & 1.5 & 194.8 \\
\hline Fine corn bran & 80.0 & 78.0 & 2.0 & 243.1 \\
\hline
\end{tabular}

Dietary fiber components and alkaline water retention capacity of wheat flour and cereal bran are shown in Table (2). Data cleared that cereal brans are excellent sources of TDF, SDF and IDF in comparison with wheat flour (82\%). Data showed also that bran of corn, barley and wheat had higher content of total and insoluble dietary
Table (3): Mineral content $(\mathrm{mg} / \mathrm{100g})$ of cereal bran:

\begin{tabular}{|l|c|c|c|c|c|}
\hline \multicolumn{1}{|c|}{ Raw materials } & Fe & Zn & Ca & K & Mn \\
\hline Wheat flour $(82 \%)$ & 1.9 & 2.0 & 22.0 & 315 & 0.5 \\
\hline Coarse wheat bran & 12.2 & 4.2 & 25.5 & 800 & 2.0 \\
\hline Fine wheat bran & 12.0 & 3.8 & 23.8 & 740 & 1.8 \\
\hline Coarse barley bran & 14.4 & 7.0 & 30.4 & 750 & 2.2 \\
\hline Fine barley bran & 13.5 & 6.0 & 28.1 & 730 & 2.0 \\
\hline Coarse oat bran & 9.7 & 3.8 & 40.2 & 750 & 3.0 \\
\hline Fine oat bran & 7.2 & 3.2 & 36.3 & 700 & 2.8 \\
\hline Coarse sorghum bran & 5.5 & 1.6 & 18.5 & 250 & 1.2 \\
\hline Fine sorghum bran & 5.4 & 3.3 & 15.8 & 400 & 1.9 \\
\hline Coarse corn bran & 2.9 & 1.4 & 14.0 & 250 & 0.6 \\
\hline Fine corn bran & 3.1 & 1.6 & 13.1 & 300 & 0.7 \\
\hline
\end{tabular}

fiber in comparison with sorghum and oat. In contrast, bran of barley and oat had higher content of soluble dietary fibers in comparison with wheat, sorghum and corn. Although barley has not traditionally been roller-milled like wheat to obtain flour and bran, this may change in the near future because of barley's high soluble fiber content and its potential use in many food products (Zheng et al., 2011). Also, data cleared that fine bran had higher water holding capacity in comparison with coarse bran. Data showed also that fine bran of barley, oat and wheat had higher water holding capacity in comparing with sorghum and corn.

\subsection{Mineral content of wheat flour and cereal brans}

Mineral content of wheat flour and cereal bran is shown in Table (3). Data showed that wheat, barley, oat and sorghum brans are good sources of iron, zinc and calcium in comparison with wheat flour (82\%). Data showed also that coarse bran content of these minerals was higher than fine bran. Similar results in mineral content of barley bran were found by Bhatty, (1993).

\subsection{Effect of particle size of cereal bran on the} chemical composition and energy level of high fiber bread

Effect of particle size of cereal bran on the chemical composition and energy level of high fiber bread is shown in Table (4). Data showed that cereal bran increased total dietary fiber content of the high fiber bread. On the other hand, data cleared that cereal brans decreased 
Table (4): Effect of particle size of cereal brans on chemical composition of the high-fiber bread.

\begin{tabular}{|l|c|c|c|c|c|c|}
\hline High fiber bread with: & $\begin{array}{c}\text { Carbohy } \\
\text { drates } \\
(\boldsymbol{\%})\end{array}$ & $\begin{array}{c}\mathbf{T D F}^{\mathbf{a}} \\
\mathbf{( \% )}\end{array}$ & $\begin{array}{c}\text { Protein } \\
\mathbf{S} \\
(\boldsymbol{\%})\end{array}$ & $\begin{array}{c}\text { Fats } \\
(\boldsymbol{\%})\end{array}$ & $\begin{array}{c}\text { Ash } \\
(\boldsymbol{\%})\end{array}$ & $\begin{array}{c}\text { Energy } \\
(\text { Kcal) }\end{array}$ \\
\hline Control & 79.72 & 5.0 & 12.7 & 1.50 & 1.08 & 383.18 \\
\hline Coarse wheat bran & 74.62 & 9.4 & 12.8 & 1.67 & 1.51 & 364.71 \\
\hline Fine wheat bran & 75.03 & 9.0 & 12.9 & 1.68 & 1.39 & 366.92 \\
\hline Coarse barley bran & 76.36 & 8.3 & 12.2 & 1.58 & 1.56 & 368.46 \\
\hline Fine barley bran & 76.54 & 8.1 & 12.3 & 1.48 & 1.58 & 368.68 \\
\hline Coarse sorghum bran & 76.2 & 8.5 & 12.7 & 1.45 & 1.15 & 368.65 \\
\hline Fine sorghum bran & 76.47 & 8.1 & 12.7 & 1.55 & 1.18 & 360.63 \\
\hline Coarse oat bran & 76.12 & 7.5 & 13.0 & 1.90 & 1.48 & 373.58 \\
\hline Fine oat bran & 76.22 & 7.2 & 13.1 & 1.92 & 1.56 & 374.56 \\
\hline Coarse corn bran & 73.05 & 12.1 & 11.9 & 1.55 & 1.40 & 353.75 \\
\hline Fine corn bran & 72.62 & 12.6 & 12.1 & 1.53 & 1.15 & 352.65 \\
\hline
\end{tabular}

${ }^{a}$ refer to total diety fibers, $s$

Table (5): Effect of particle size of cereal brans on the dietary fiber component and moisture content of high fiber bread:

\begin{tabular}{|l|c|c|c|c|}
\hline Bread with 10\% of: & $\begin{array}{c}\text { TDF } \\
(\boldsymbol{\%})\end{array}$ & $\begin{array}{c}\text { IDF } \\
(\boldsymbol{\%})\end{array}$ & $\begin{array}{c}\text { SDF } \\
(\boldsymbol{\%})\end{array}$ & $\begin{array}{c}\text { Moist } \\
\text { ure } \\
(\%)\end{array}$ \\
\hline Control & 5.0 & 3.5 & 1.5 & 34.3 \\
\hline Coarse wheat bran & 9.4 & 7.3 & 1.8 & 38.2 \\
\hline Fine wheat bran & 9.0 & 7.1 & 2.1 & 40.4 \\
\hline Coarse barley bran & 8.3 & 6.5 & 1.8 & 38.7 \\
\hline Fine barley bran & 8.1 & 6.1 & 2.0 & 40.6 \\
\hline Coarse sorghum bran & 8.5 & 6.1 & 2.4 & 37.9 \\
\hline Fine sorghum bran & 8.1 & 5.7 & 2.4 & 38.5 \\
\hline Coarse oat bran & 7.5 & 5.5 & 2.0 & 39.2 \\
\hline Fine oat bran & 7.2 & 5.2 & 2.0 & 40.5 \\
\hline Coarse corn bran & 12.1 & 10.5 & 1.6 & 39.8 \\
\hline Fine corn bran & 12.6 & 10.9 & 1.7 & 40.4 \\
\hline
\end{tabular}

carbohydrates and energy level of the high fiber bread. Data showed also that except for corn and oat brans, coarse brans of cereal decreased carbohydrate level of bread more than the fine brans. Data cleared also that except for corn bran, coarse bran of cereal increased TDF content of bread more than the fine bran.

3.5. Effect of particle size of cereal brans on the dietary fiber component and moisture level of high fiber bread

Effect of particle size of cereal brans on the dietary fiber component and moisture content of high fiber bread are shown in Table (5). Data showed that cereal bran increased TDF, IDF, SDF and moisture content of the high fiber bread. Data cleared also that coarse bran of cereal decreased moisture content of the high fiber bread more than the fine bran. Sosulski and $\mathrm{Wu},(1988)$ found that total dietary fiber contents of the acceptable fiber breads were $21 \%$ for corn bran, $13 \%$ for wheat bran and $6 \%$ for wild oat bran breads.

3.3.6.Effect of brans particle size on sensory properties of the high fiber balady bread

Effect of bran particle size on sensory properties of the high-fiber balady bread are presented in Table (6). Data showed that cereal bran significantly decreased the sensory properties of the high-fiber balady bread. Also, coarse bran reduced the sensory properties of the high-fiber balady bread more than the fine bran. Data demonstrated also that sensory properties of the high-fiber balady bread with bran of sorghum, barley and wheat were more acceptable than balady bread with bran of oat and corn.

3.7. Effect of particle size of bran on alkaline water retention capacity of balady bread

Effect of bran particle size on alkaline water retention capacity of balady bread is shown In Table (7). Data demonstrated that brans increased alkaline water rentation capacity of fresh balady bread in comparison with the control balady bread due to its high dietary fiber content. These results agreed withKim and D'Appolonia (1997). They mentioned that presence of dietary fibers such as insoluble arabinoxylans increased water absorption during bread making. Sosulski and $\mathrm{Wu}$, 
Table (6): Effect of bran particle size on sensory properties of balady bread.

\begin{tabular}{|l|c|c|c|c|c|c|c|}
\hline Bread with 10\% of: & $\begin{array}{c}\text { Appea } \\
\text { rance } \\
\mathbf{( 1 5 )}\end{array}$ & $\begin{array}{c}\text { Layers } \\
\text { separat } \\
\text { ion } \\
(\mathbf{1 5})\end{array}$ & $\begin{array}{c}\text { Crumb } \\
\text { texture } \\
\mathbf{( 1 5 )}\end{array}$ & $\begin{array}{c}\text { Crust } \\
\text { color } \\
\mathbf{( 1 5 )}\end{array}$ & $\begin{array}{c}\text { Taste } \\
\mathbf{( 2 0 )}\end{array}$ & $\begin{array}{c}\text { Odor } \\
\mathbf{( 2 0 )}\end{array}$ & $\begin{array}{c}\text { Overal } \\
\mathbf{1} \\
\text { accept } \\
\text { ability } \\
(\mathbf{1 0 0})\end{array}$ \\
\hline Control & $15.0^{\mathrm{a}}$ & $15.0^{\mathrm{a}}$ & $15.0^{\mathrm{a}}$ & $14.0^{\mathrm{a}}$ & $18.0^{\mathrm{a}}$ & $18.0^{\mathrm{a}}$ & $95.0^{\mathrm{a}}$ \\
\hline Coarse wheat bran & $12.5^{\mathrm{c}}$ & $13.0^{\mathrm{bc}}$ & $12.5^{\mathrm{b}}$ & $14.0^{\mathrm{a}}$ & $16.0^{\mathrm{b}}$ & $16.0^{\mathrm{b}}$ & $86.0^{\mathrm{b}}$ \\
\hline Fine wheat bran & $14.0^{\mathrm{ab}}$ & $14.0^{\mathrm{ab}}$ & $13.0^{\mathrm{b}}$ & $14.0^{\mathrm{a}}$ & $17.0^{\mathrm{ab}}$ & $17.0^{\mathrm{ab}}$ & $89.0^{\mathrm{a}}$ \\
\hline Coarse barley bran & $14.0^{\mathrm{ab}}$ & $14.0^{\mathrm{ab}}$ & $13.0^{\mathrm{b}}$ & $14.0^{\mathrm{a}}$ & $17.0^{\mathrm{ab}}$ & $17.0^{\mathrm{ab}}$ & $89.0^{\mathrm{a}}$ \\
\hline Fine barley bran & $14.0^{\mathrm{ab}}$ & $14.0^{\mathrm{ab}}$ & $13.0^{\mathrm{b}}$ & $14.0^{\mathrm{a}}$ & $17.0^{\mathrm{ab}}$ & $18.0^{\mathrm{a}}$ & $90.0^{\mathrm{a}}$ \\
\hline Coarse sorghum bran & $13.0^{\mathrm{bc}}$ & $14.0^{\mathrm{ab}}$ & $13.0^{\mathrm{b}}$ & $14.0^{\mathrm{a}}$ & $17.0^{\mathrm{ab}}$ & $18.0^{\mathrm{a}}$ & $89.0^{\mathrm{a}}$ \\
\hline Fine sorghum bran & $13.0^{\mathrm{bc}}$ & $14.0^{\mathrm{ab}}$ & $13.0^{\mathrm{b}}$ & $14.0^{\mathrm{a}}$ & $18.0^{\mathrm{a}}$ & $18.0^{\mathrm{a}}$ & $90.0^{\mathrm{a}}$ \\
\hline Coarse oat bran & $12.5^{\mathrm{c}}$ & $13.0^{\mathrm{bc}}$ & $12.5^{\mathrm{b}}$ & $13.0^{\mathrm{b}}$ & $14.0^{\mathrm{c}}$ & $15.0^{\mathrm{bc}}$ & $79.0^{\mathrm{c}}$ \\
\hline Fine oat bran & $13.0^{\mathrm{bc}}$ & $12.5^{\mathrm{c}}$ & $12.5^{\mathrm{b}}$ & $13.0^{\mathrm{b}}$ & $14.0^{\mathrm{c}}$ & $15.0^{\mathrm{bc}}$ & $80.0^{\mathrm{bc}}$ \\
\hline Coarse corn bran & $12.0^{\mathrm{c}}$ & $12.6^{\mathrm{c}}$ & $12.4^{\mathrm{b}}$ & $13.0^{\mathrm{b}}$ & $16.0^{\mathrm{b}}$ & $16.0^{\mathrm{b}}$ & $82.0^{\mathrm{bc}}$ \\
\hline Fine corn bran & $13.0^{\mathrm{bc}}$ & $13.5^{\mathrm{bc}}$ & $13.5^{\mathrm{b}}$ & $14.0^{\mathrm{a}}$ & $15.0^{\mathrm{bc}}$ & $14.0^{\mathrm{c}}$ & $83.0^{\mathrm{bc}}$ \\
\hline
\end{tabular}

Table (7): Effect of bran particle size on alkaline water retention capacity of balady bread.

\begin{tabular}{|l|c|c|c|}
\hline \multirow{2}{*}{ Bread with 10\% of: } & \multicolumn{3}{|c|}{$\begin{array}{c}\text { Alkaline water retention } \\
\text { capacity after: }\end{array}$} \\
\cline { 2 - 4 } & Fresh & $\mathbf{1 2}$ hr & $\mathbf{2 4 ~ h r}$ \\
\hline Control & 386 & 305 & 270 \\
\hline Coarse wheat bran & 461 & 433 & 402 \\
\hline Fine wheat bran & 481 & 452 & 424 \\
\hline Coarse barley bran & 471 & 450 & 428 \\
\hline Fine barley bran & 520 & 500 & 482 \\
\hline Coarse sorghum bran & 431 & 403 & 387 \\
\hline Fine sorghum bran & 441 & 419 & 389 \\
\hline Coarse oat bran & 460 & 442 & 420 \\
\hline Fine oat bran & 474 & 450 & 433 \\
\hline Coarse corn bran & 451 & 430 & 411 \\
\hline Fine corn bran & 461 & 440 & 418 \\
\hline
\end{tabular}

(1988) and De Kock et al., (1999) reported that wheat and oat bran increased water absorption of dough. Data showed also that fine brans increased alkaline water retention capacity in the high fiber balady bread more than the coarse bran. Also, fine barley brans increased alkaline water retention capacity in the high-fiber balady bread more than other brans. Data in Table (7) cleared also that alkaline water retention capacity of the high-fiber balady bread decreased with increasing the storage time. Also, brans altered the staling rate of bread in comparison with the control bread and fine barley bran recorded the highest freshness in the produced balady bread. These results agreed with Assel (2012) who reported that addition of whole naked barley flours to whole wheat flour led to decrease in balady bread staling rate and increased its freshness.

\section{REFERENCES}

A.O.A.C. (2005). Official methods of Analysis of the Association of Official Analytical Chemists. Arlington, Virginia,USA.

Assel S. (2012). Studies on utilization of barley flour in the production of bread. M. Sc. Thesis, Fac., Agric., Zagazig Univ., Egypt.

Bhatty R. (1993). Physicochemical properties of roller milled barley bran and flour. Cereal Chem., 70: 4, 397- 402.

Campbell G. (2003). Bread Aeration. Pages 352374 in Breadmaking: Improving Quality. Cauvain S.P. (Ed.), Woodhead Publishing Ltd., Cambridge, UK.

Chen H., Haack V., Corey W., Nicholas W. and Judith A. (1998). Mechanisms by which wheat bran and oat bran increase stool weight in humans. Am. J. Clin. Nutr., 68, 711-719.

Cho S., Clark C. and Uribe-Saucedo S. (2004) Gastrointestinal and other physiological effects of wheat bran. Cereal Foods World 49(3):140144.

Chronakis I, Triantafyllou A. and Öste R. (2004). Solid-state characteristics and redispersible 
properties of powders formed by spray-drying and freeze-drying cereal dispersions of varying $(1 \rightarrow 3,1 \rightarrow 4)$ - $\beta$-glucan content. J. Cereal Sci., 40: 183-193.

De Delahaye Pacheco E., Jimenez P. and Perez E. (2005). Effect of enrichment with high content dietary fiber stabilized rice bran flour on chemical and functional properties of storage frozen pizzas. J. Food Eng. 68:1-7.

De Kock S., Taylor J. and Taylor N., (1999). Effect of heat treatment and particle size of different brans on loaf volume of brown bread. Lebensm. Wiss. Technol., 32:349-356.

FAO/ WHO. 1974. Handbook on human nutritional requirements. Published by FAO, p.53-63, Rome.

Faridi, H. and Rubenthaler, G. (1984). Effect of baking time and temperature on bread quality, starch gelatinization and staling of Egyptian balady bread. J. Cereal Chem., 61 (2): 151.

Kim S. and D'Appolonia B. (1997). Bread staling studies. 3. Effect of pentosans on dough, bread, and bread staling rate. Cereal Chem., 54:225229.

Kitterman, S. and Rubenthaler, E. (1971). Assessing the quality of early generation wheat selection with micro A.W.R.C. Test. J. Cereal Sci. Today, $16:$ 313-316.

Kumar, P., Yadava, R., Gollen, B., Kumar, S., Verma, R. and Yadav, S. (2011). Nutritional contents and medicinal properties of wheat: a review. Life Sci. and Medicine Research, 22, 1- 10.

McClave, J. and Benson, G. (1991): Statistics for business and economics. Dellen Publishing, Fifth Edition. San Francisco, USA.

Meyer, K., Kushi, L. Jacobs, D., Slavin, J., Sellers, T. and Folsom, A. (2000). Carbohydrates, dietary fiber, and incident type 2 diabetes in older women. Am. J. Clin. Nutr., 71, 921-930.

Murtaugh M., Jacobs D., Steffen L. and Marquart L. (2003). Epidemiological support for the protection of whole grains against diabetes. Proc. Nutr. Soc., 62(1): 143-149.

Ozturk, S., Ozpoy, O., Cavidoglu, L. and Koksel, H. (2002). Effect of brewers spent grain on the quality and dietary fiber content of cookies. J. Inst. Brew. 108 (1): 23- 27.

Park, Y., Brinton, L., Subar, A., Hollenbeck, A. and Schatzkin, A. (2009). Dietary fiber intake and risk of breast cancer in postmenopausal women: The National Institutes of HealthAARP Diet and Health Study. Am. J. Clin. Nutr., 90, 664-671.

Sallam, I., Abd El-Magid, M., Hegazy, N. and Abou Zaid, W. (1995). Effect of packaging and storage on bread containing additives to retard stalling. Egypt. J. Food Sci., 23(1): 133-145.

Sosulski F. and Wu K. (1988). High-fiber breads containing field pea hulls, wheat, corn and wild oat brans. Cereal Chem. 65:186-191.

Streppel, M., Ocke, M., Boshuizen, H., Kok, F. and Kromhout, D. (2008). Dietary fiber intake in relation to coronary heart disease and allcause mortality over 40 y: The Zutphen Study. Am. J. Clin. Nutr., 88, 1119-1125.

Tucker, L. and Thomas, K. (2009). Increasing total fiber intake reduces risk of weight and fat gains in women. J. Nutr., 139, 576-581.

Viuda-Martos M., Ruiz-Navajas Y., FernandezLopez J. and Perez-Alvarez J. (2010). Effect of orange dietary fibre, oregano oil and packaging conditions on shelf-life of bologna sausages. Food Control, 21: 436- 443.

Watson S. (2003). Description, development, structure, and composition of the corn kernel, in Corn: Chemistry and Technology, ed. by White PL and Johnson LA. American Association of Cereal Chemists, St Paul, MN, pp. 69-106.

Zheng, X., Li, L. and Wang, Q. (2011). Distribution and molecular characterization of $\beta$-glucans from hull-less barley bran, shorts and flour. Int. J. Mol. Sci., 12, 1563-1574. 


$$
\text { تأثير حجم حبيبات ردة بعض الحبوب علي جودة الخبز البلدي عالي الألياف مبروك عراقي - نبيل عبد الفتاح علي ـ عبد التواب سعد بركات بحوث تكنولوجيا الأغذية ـ مركز البحوث الزر اعية ـ الجيزة }
$$

\section{ملخص}

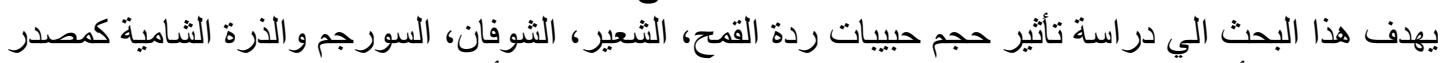

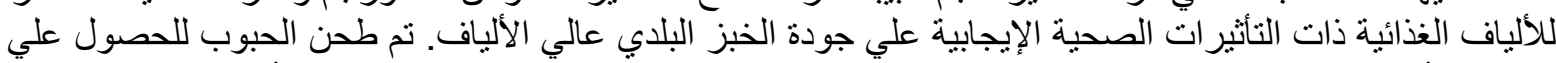

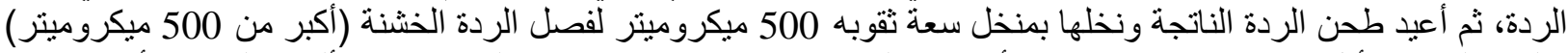

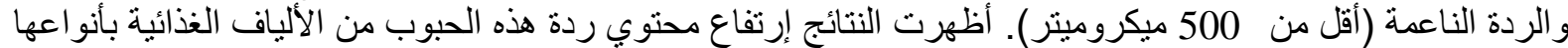

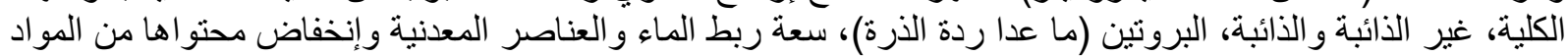

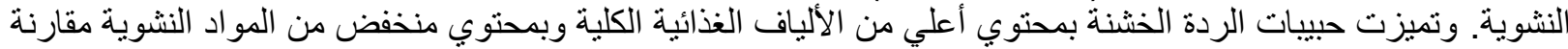

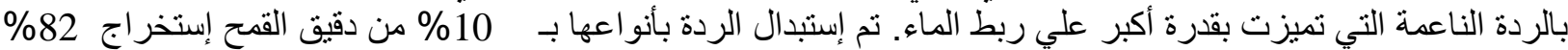

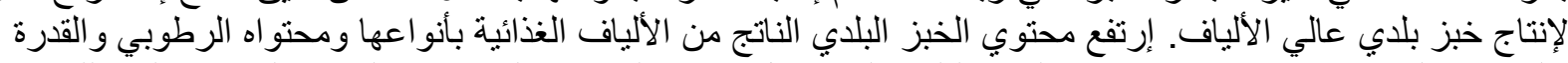

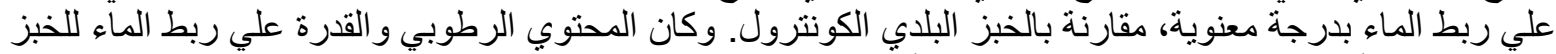

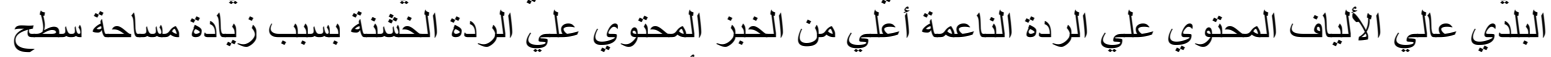

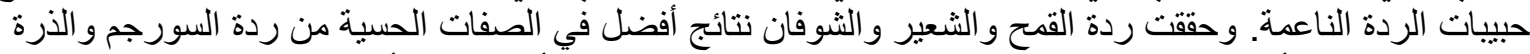

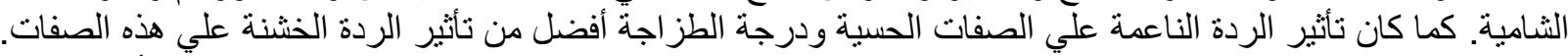

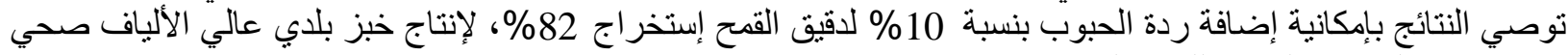
دون تدهور الصفات الحسية للخبز الناتج. 